\title{
SCIENTIFIC WRITING
}

\author{
By Prof.Drs.Seno H Putra, M.Pd.,Ph.D \\ (Linguistic Professor of English Department of FKIP, UIR, \\ Pekanbaru, Riau, Indonesia)
}

\section{What is Paragraph?}

A Paragraph is a basic unit of Organization in Writing, in which a group of related sentences developes one main idea. A paragraph can be as short as one Sentence or as long as ten Sentences. The number of Sentences is unimportant; however, the paragraph should be long enough to develop the main idea clearly. Moreover, There are three parts of a Paragraph. They are: a Topic Sentence, Supporting Sentences, and a Concluding Sentence (Oshima, 1981)

The Topic Sentence states that the main idea of the Paragraph, and it also limits the topic to one or two areas that can be discussed completely in the space of a single Paragraph. However, the specific area is called the Controlling Idea.

Example, the Topic Sentence explains both the Topic and Controlling Idea.

\section{(Topic)}

\section{(Controlling Idea)}

Disaster, occurs most of the World not only in Indonesia, but also other Countries, such as (Earthquake, Mude Flow, Flooting, Land Flow, Whirlwind, etc., since 2004 untill now) (Seno H.Putra, 2007)

Supporting Sentences develop the Topic Sentence, where they explain the Topic Sentence by giving Scientific reasons, 
examples, pure Data, Facts, Statistics, Tables, etc., to support the Topic Sentence itself.

Concluding Sentence explains the end of the Paragraph and reminds the readers the important points.

Unity explains and discuss only one main idea in a Paragraph as You introduce the ("What, how, why, where, etc., of the Disaster is").

Coherence refers to the readers that your own Paragraph is easy to understand, and it must be excellent to put the approriate transitional words in a Paragraph.

Writing is more structure or organize than spoken, since the writer must be able to organize his own ideas through out the organization of Writing. Moreover, Writing is like the body of human, which encompasses (Head, Body, and Legs), and these must link one another to achieve the purpose of ideas (Seno H.Putra, 1992-2005).

Seno H.Putra (2004)

Find out Titles of Scientific Writing

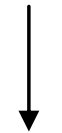

\section{Phenomena of the World}

The World created by the God, it encompasses a lot of species, like Natural sources, human beings, Plantations, Animals,etc., which can be developed by Human throughout Education, Science and Technology that can be splitted to be the following items: 
1. Natural

Science(Physics;Biology;Mathematics;Chemistry;Technics;Indu stry,etc.,;

2. Social Science (Law;Economy;Politics;Psychology, etc.,;

3. Language Science (Linguistics Science);

4. Applied Science;

5. Literature Science;

6. Anthropological Science;

7. Sociological Science;

8. Health Science, etc.

From the above Sciences can be found out many phenomena in Scientific Writing and Research. However, as Writers or Researchers must limit those problems to become "A Title" as well as to make it out in Scientific Writing. Therefore, candidate Scholars are expected not only to read, exercises, and write, but also to be able to observe and look over what the phenomena in the World.

As Writers and Researchers, in addition to, must be able to play with Words and Sentences in Scientific Writing even though they have a lot of concepts and ideas in their minds. Besides, they have to think over essential language used in Scientific Writing, for example, if English used in your Writing, you must consider the systems, rules, words, sentences, etc., are in English accepted by Native Speakers (Seno H.Putra, 1999).

Those who are beginners (not accustomed to Writing), they are hoped to perform "An Outline" of Writing. This is to make Writers easy to start and organize the ideas not only in a paragraph, but also a few paragraphs in a Scientific Writing. An outline can be divided into several sub-topics depending on how many paragraphs that the writers would like to write based on the title. See an Example below: 


\section{Earthquake}

By Seno H.Putra (2005)

A. Starting from 2004 until at Present, Indonesia and other Countries in the World have been earthquake.

B. Earthquake in Indonesia

- $\quad$ Aceh (Tsuname);

- Nias

- $\quad$ Padang

- Yogya

C. Population

- $\quad$ How many People are Wounded

- $\quad$ How many People are killed

- $\quad$ Female

- Male

- $\quad$ Children and Old People

D. Contribution

- Inside Contributors

- $\quad$ Outside Contributors

E. Solutions of Earthquake

F. Conclusions and Recommendations

\section{Kinds of Writing}

There are a few of kinds of Writing known in the Academic World. They are:

1. Descriptive Writing; 
2. Comparative and Contrast Writing;

3. Argumentative Writing;

4. Analytical Writing;

5. Cause and Effect Writing;

6. Factual Narrative Writing; etc.

\section{Forms of Writing}

There are two forms of Writing, one belongs to Formal Writing and another one is non-Formal Writing. However, according to the use of Writing, there are Popular Writing and Scientific Writing.

\section{Choose Exact Words and Sentences}

Words and Sentences are the key in Writing. To describe and explain our ideas through out Writing, the Writer must be able to choose the exact Words, since every Word of a Language has a particular meaning semantically, and so does in every Sentence of a Language, in which it also has a particular one grammatically, so that both writer and readers have misinterpretation to those in Writing (Seno H.Putra, 2005).

Seno H.Putra (2004)

\section{Mud Flow \\ By Seno H.Putra}

Indonesia since 2004 until at present has had many Natural phenomena, for example, Earthquake, Flooting, Land flow, Mud flow, etc. One of the other Natural phenomena still occurs up to 
now in Indonesia is Mud flow. Mud flow happens in Sidoarjo, East Java, and this occurs in this area is one side because of over process of digging mine for Natural gas; and other side might be caused by Human errors that are not able to look after Natural and Human Environment.

Mud flow, furthermore, can be negative effect to people who live in its Environment, for examples; people lost facilities, Houses, and their Children do not concentrate to go to School, as well as other activities. Most of the Citizen are evacuated by the Government to other places to have stay. Even though the Mud flow had been solved and anticipated by the local and national governments until at present, it still flows, and even it has covered most of the Land in its surroundings. Many Experts inside and outsiders and Science and Technology, and other tools of Technology have involved to overcome the Mud flow at Sidoarjo, it can not be solved by human and technology. Therefore, these are also our tasks, Why the Mud flow at Sidoarjo can not be anticipated by Human and Technology? Also, Billion Rupiah has been run out for this, some of people have been sacrifice of the mud flow?

Therefore, the Mud flow and other Earthquakes in our Country or out of the Countries not only blame the Environment which has been created by the God, but also the cases of Nature must be blamed to the Human errors, in which those have explorated the Natural sources over than the needs of Nature, so that it might be the negative effects of other species live in its Environment. Besides, Human also has destroyed Nature without thinking other effects, and they only think Money minded and Economical minded. So, this problem must be flashed back to each Human who wants to think it over. 


\section{Seno H.Putra (2007) \\ Scholars Who Believe in God}

\section{By Seno H.Putra}

Most of the People in the World have Education starting from Kindergaten until University which also have levels of Degree, for example, the first University Degree, Master Degree, and Ph.D (Doctor) Degree. They have Education to develop theirselves in Economy aspects and to Master Science and Technology. For those who have Education in high level are usually called as Scholars, and their functions after graduation from University not only to themselves, but also they can contribute their fields of Science to Community activities.

In addition to this, the Scholars are expected to believe in God, since they have been created by the God according to their abilities, forms, and various colours, as well as levels of position in their life in the World. Scholars, moreover, who only think the Science and the World, they can be called as "Schulars". However, those who think both Science and Technology and World, as well as hereafter, or believe in God are the best Scholars in the side of God. Therefore, the belief and faith in God is the key to carry out everything whether in the World or in hereafter. In short words, the World life is temporary; while hereafter is everlasting life forever. You may pick out which one do you like "Hell or Heaven"?

Besides the ideas above, we frequently look over that some of inside or outside Scholars are proud of their own Degrees, Sciences, and Skills - even what they have now is for a 
while given by the God, therefore, they are sometimes forgetful in themselves and God. In other words, after having many levels of Degrees, they believe that everything is enough for them without belief and faith in God, and they do not want to read a lot, exercises very often, practice, search for something to add and dig their own knowledge. The kinds of these Scholars are very dangerous at present and for the future, as well as for the Nations.

The Scholars, on the other hand, who are interested to learn, read a lot, exercises, practice, and look over very often, as well as belief and faith in God are the Scholars of low profiles. They realize that the Degrees that they belong to now not only derived their own efforts, but also those are honored by the supreme of God, so that what they had already obtained make them aware if it is compared to the creation and the ability of the God in the World and Heaven. No body can fight and compete Him in this World! Consequently, we can choose which Scholars to be followed whether "Schulars or belief in God and low profile", or everything coming back to each individual.

Pekanbaru, Sept 21-007

\section{Seno H.Putra (2007) EDUCATION IN INDONESIA By Seno H.Putra}

There are a few of systems of Education in Indonesia applied by our Government under the Department of Education. One is Colonisms systems; and the others are American and British systems, and the last National and Local systems. These systems of Education have been used according to each 
Curriculum and the ways of Teaching and Learning Processes in the Classroom and Lab, or in the field.

The Colonisms systems, where the Education in Indonesia only offered to those who had high level positions whether in Bureaucracy or Community. These systems did not offer Education which made the Citizens to be self confidence to their Country or love Indonesia much; however, they more focused on the Colonist systems, so that most of Indonesian to be separated from one region to other regions. Moreover, Colonists systems were very limited to all Indonesian, and Education at that was not balance to every level of Education. A great number of Indonesian to be hard and forced labour, for examples, to be Farmers, to be Workers of the roads, only few of them to be Civil servant Government, or Bureaucracy. In other words, many Indonesian at that Colonists systems to be Slavers at each place of Indonesian Archipelago. These cases were not only occurred in Dutch Colonisms, but also Japanese Colonists.

American, on the other hand, its systems of Education, in which the Students are offered credits of Courses (Subject Matters) for every semester, those are also given tasks or assignments, as well as the Students are expected to attend the Class to join Lectures with Lecturers. Final projects (Assignments) whether individual, pairs, or in groups and attendance the meeting in the Classroom or Labor are the must for the Students. Giving the tests are not enough yet, but must be assisted and added with assignments, presentations, and instruments, so that the Students will obtain Sciences in a few of Skills.

In addition to this, European systems are contrary to American ones, where the European systems meetings and attendance the Classroom or Labour are not (necessary), but more focuses on individual Study, do exercises individually, etc. 
Even though this systems perform the Students more independence rather than depending on others in the Teaching Learning Processes. Besides that, the Students are expected to learn with complete facilities provided by University, such as module, Library, long distance modules, etc., function to talk over with Lecturers. Although such systems, the tests of each semester must be done and followed by the Students.

Indonesian Education systems after independence, they applied both systems whether American or European systems. In contrast, every University in Indonesia at present must follow the National Curriculum which can be advanced to the regions of Indonesia. However, Indonesian Education systems always change the Curriculum, for examples, starting from 1975 Curriculum, 1984 Curriculum, 1994 Curriculum, 2004 Curriculum, and also 2006 and 2013 Curriculum. Why the systems of Education in Indonesia frequently change mostly the years? According to my opinions, the change of Curriculum is not guarantee to increase the Human sources, but the most important thing that I recommend to whom it may concern is to make teachers welfare, to provide facilities both Teachers and Students, as well as offering Scholarships for those who have excellent qualifications in Academic World. In summary, although several Education systems had been used in Indonesia, the most important thing how the candidate Scholars or scholars are able to create and develop Science and Technology for Community activities whether Local, National, or International, and those also compete with mastery of Science and Technology globally. Therefore, scholars must be diligent, discipline, more creativity not only Teaching and Learning, Science and Technology, but also be able to become Religious Scholars.

\section{Pekanbaru, 27/09/007}




\section{Solution}

Academic Writing (Scientific Writing) also has other Characteristics. They are: 1) Clearly Explanation; 2) Frozen, Standard, and precise Sentences and Clauses; 3) to the points of the Problems which are explained and researched by the Researcher; 4) Rhetoric; 5) Argumentations; 6) find out, dig, elicit, and present the Data whether Qualitative or Quantitative Approaches, or both approaches can be combined after the analysis process; 7) the Data can be analyzed through out Qualitative approach that modifies clearly and detail explanations based on the standard Language; and 8) Quantitative approach which the data obtained from the sample, or informants must be analyzed through out statistical formula (Seno Putra, 2001).

Moreover, Academic Writing frequently has several formats. Format I has five Chapters; Format II has 6 Chapters; Format III encompasses 7 Chapters, and another Format sometimes consists 8 Chapters. Therefore, when you write Thesis and Dissertation, you must follow the formats used by your own University, as well as suggestions or recommendations from your Supervisors.

In Academic writing, if you encounter any difficulties to write and complete your own writing, you are expected not to get nervous and bored, you must be relax, and ask your supervisors, discuss with them, then you can read a lot of references, as well as discuss it with your friends who know and understand your own writing, but you are not allowed to ask and pay someone to write and make your writing, it is 
not a good behavior to obtain your Scholar. Therefore, again, you are also suggested to understand and master the formal Language and its components, structure, spelling, mechanics of writing, systems and styles of Language, as well as organization of writing. In short, all aspects mentioned above needed by someone who wants to write.

After all aspects were completed, You also need to attach all references, such as Articles, Papers, Newspapers, Magazines, Books, Journals, Scripts, Thesis, Dissertations, etc., which have been read and quoted by You on Bibliography, so that You can honor Someone's Writings even an article. You know that "Writing" is difficult for You, so You must honor the previous Writers' Writings.

\section{References}

Barnett Carosso, Rebecca; Dupras Stanford, Judith.1983. The Writing Connection.New Jersey:Englewood Cliffs.

Osima, Alice and Hogue, Ann. 1981. Writing Academic English.Massachusetts: Addition-Wesley Publishing Company.

Pedoman Pengindonesiaan Nama dan Kata Asing.1995.Jakarta:Balai Pustaka.

Seno, Putra.2000. Analisis Wacana dan Bahasa Media. Makalah Bulan Bahasa.Pekanbaru:FKIP,UIR.

Seno,Putra.2007.Pengenalan Metodologi Penelitian.Pekanbaru:Reset Riau.

Seno,Putra.2005. English Syntax and English Semantics.Pekanbaru: Reset Riau.

Seno, Putra.2006. Introduction to General Linguistics.Pekanbaru:UNRI Press. 
